\title{
Trophy Hunting and Possible Source-Sink Dynamics in Protected Areas: Insights from Trophy Size and Offtake Patterns in Southeast Zimbabwe
}

\author{
Augustine Jeke, ${ }^{1}$ Admire Chanyandura, ${ }^{1}$ Victor K. Muposhi $\left(\mathbb{D},{ }^{1}\right.$ \\ Daphine Madhlamoto, ${ }^{2}$ and Edson Gandiwa $\mathbb{D}^{1}$ \\ ${ }^{1}$ School of Wildlife, Ecology and Conservation, Chinhoyi University of Technology, Private Bag 7724, Chinhoyi, Zimbabwe \\ ${ }^{2}$ Scientific Services, Gonarezhou National Park, Parks and Wildlife Management Authority, Private Bag 7003, Chiredzi, Zimbabwe
}

Correspondence should be addressed to Victor K. Muposhi; vkmuposhi@gmail.com

Received 1 November 2018; Revised 15 February 2019; Accepted 26 March 2019; Published 2 May 2019

Academic Editor: George A. Lozano

Copyright (C) 2019 Augustine Jeke et al. This is an open access article distributed under the Creative Commons Attribution License, which permits unrestricted use, distribution, and reproduction in any medium, provided the original work is properly cited.

\begin{abstract}
Developing harvest management strategies in designated hunting areas requires systematic and robust monitoring. We assessed the trophy size, quota utilization, and distribution of kill sites of African elephant, Cape buffalo, greater kudu, and leopard for the period 2007-2014 in Malapati Safari Area, southeast Zimbabwe. Trophy sizes for African elephant significantly increased over time albeit being below the expected minimum Safari Club International (SCI) score. Cape buffalo trophy sizes declined significantly over time but were not different from the SCI minimum score. However, greater kudu trophy sizes were higher than the SCI minimum score despite being constant over time. Leopard trophy sizes were higher than the SCI minimum score and increased with time. Quota utilization for African elephant and Cape buffalo increased while that of greater kudu and leopard did not change between 2007 and 2014. Some kill sites, in particular, for the African elephant and Cape buffalo, were within the buffer area with the state protected area, i.e., Gonarezhou National Park. Increased hunting pressure likely leads to poor trophy quality and hunting within the protected buffer areas. In contrast, effective adherence to hunting ethics and scientifically and conservatively set quotas largely does not compromise the trophy quality of harvested species. The observed trophy size patterns and kill sites distribution suggest the possible existence of source and sink dynamics of trophy species occurring in a protected area complex within the Zimbabwe's component of the Greater Limpopo Transfrontier Park. To ensure sustainable trophy hunting in the study area and similar ecosystems the following are recommended: (i) scientifically robust, adaptable, and participatory quota setting process, (ii) enhanced adherence to good practice in terms of ethical hunting conduct, and (iii) development of a robust hunting monitoring system covering all elements of hunting for adaptive wildlife management.
\end{abstract}

\section{Introduction}

One of the most widespread and well-practiced wildlife sustainable use option in Sub-Saharan Africa is trophy hunting $[1,2]$. Trophy hunting is defined as hunting by paying tourists, usually with the objective of selecting individuals with exceptional phenotypic traits such as large horns, tusks, body size, skull length, or mane and usually in the company of a professional hunting guide [3]. Sustainability of trophy hunting depends on the application of ecological theory [4, $5]$, in harvesting regimes as well as long term monitoring of the harvested populations [6-8]. However, if not carefully managed, the selective nature of trophy hunting may cause loss of heritable desirable traits over time $[9,10]$. The resultant phenotypic plasticity and/or evolutional change from trophy hunting induced artificial selection affect the trophy quality of preferred wildlife species by hunters [11].

The competitiveness of a trophy hunting destination may be indirectly affected by the trophy quality of the favoured wildlife species $[8,12]$. Trophy quality is a function of dimensions and the aesthetic appearance of the trophy depending on the species [13]. Over time, some negative effects of trophy hunting on the desirable phenotypic traits of selected wildlife species seem to be evident [14]. Loss of desirable phenotypic traits (i.e., horn or tusk size) with increasing trophy hunting pressure has been reported in some wildlife species [15]. A 


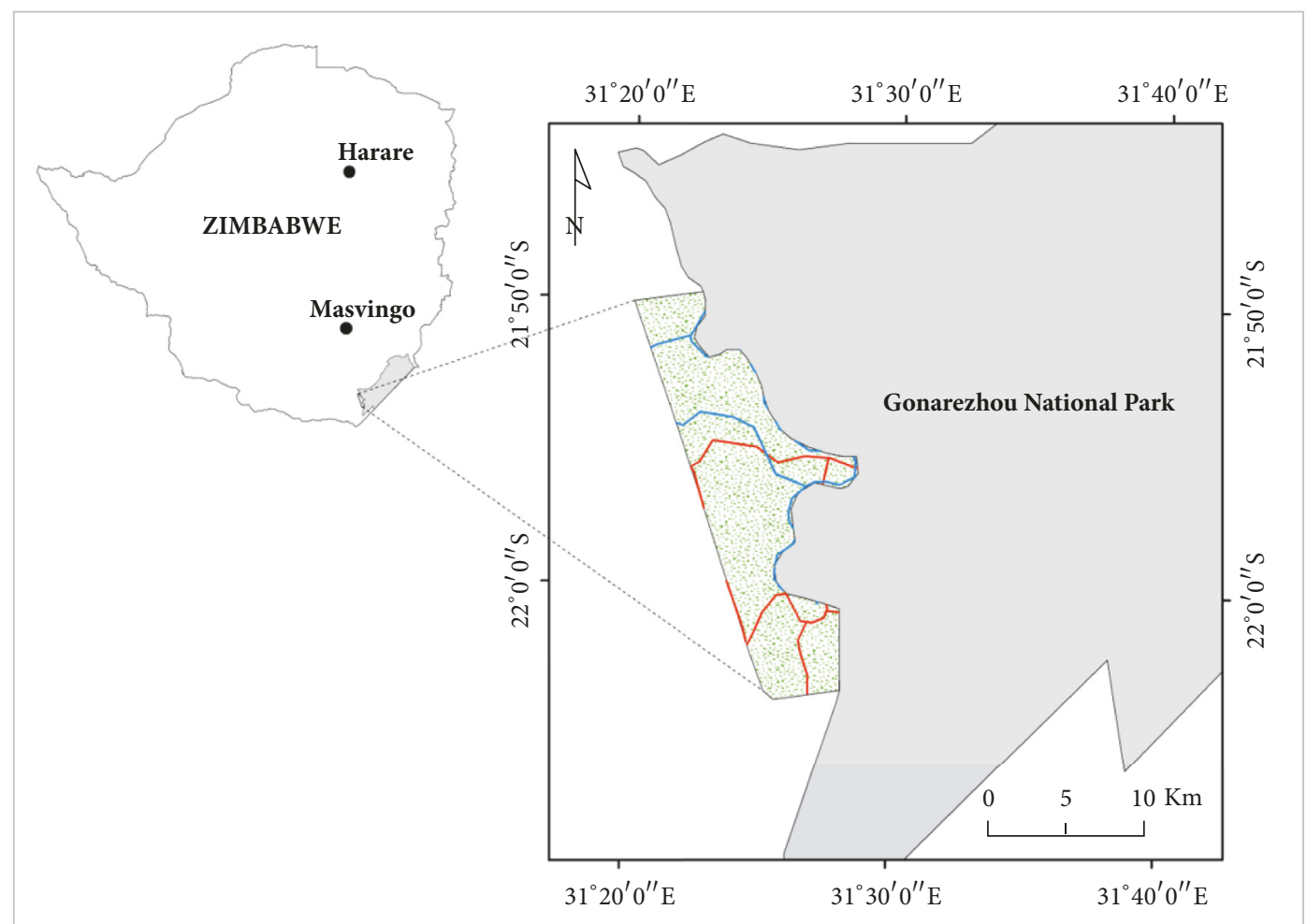

\footnotetext{
Gonarezhou NP

Malapati SA

Roads

Rivers
}

FIgURE 1: Location of study area, Malapati Safari Area adjacent to the Gonarezhou National Park, south-eastern Zimbabwe.

decline in the desirable attributes may have impact on hunter satisfaction thus resulting in low hunting quota utilization in such areas $[16,17]$. This causes much uncertainty over the sustainability of offtake rates and their potential impacts on wildlife populations [8].

In Zimbabwe, much of the trophy hunting occurs in Safari Areas which are managed mainly for the sustainable use and as buffer zones next to National Parks [8]. This arguably creates source and sink dynamics between National Parks and the Safari Areas, respectively [18]. Here, a source population is defined as one that over time portrays a minimum or no net change in its population size albeit being a net exporter of individuals [19]. On the contrary, a sink population is considered as a net importer of individuals and may not be viable in the absence of immigration due to lower productivity [20]. In this study, we considered Gonarezhou National Park (GNP), which forms part of the Greater Limpopo Transfrontier Conservation Area (GLTFCA), as a source habitat that is a net exporter of trophy individuals to the sink habitat, Malapati Safari Area. The source-sink dynamics between GNP and Malapati Safari Area is perceived to result in more individuals with desirable trophy sizes occurring in hunting area due to the vacuum effect creating by trophy hunting.

Wild male animals from protected areas may benefit from moving to hunted areas where many of their competitors may have been shot, providing a source of unselected genes that could swamp the effects of selective hunting [21]. Some studies suggest that protected areas may be regarded as sources or refuges that reduce the net ecological effects of selective harvesting in the adjacent hunted areas [22]. These refugee areas or populations are a source of unselected immigrants (i.e., trophy individuals) into harvested populations. We argue that, where dispersal is sufficient enough, emigration from source areas (i.e., National Parks) into sink areas (i.e., Safari Areas) may counteract the possible phenotypic impacts of selective harvesting [23]. In this study, we investigated the trophy size, quota utilization, and kill sites of four selected wildlife species (i.e., three large herbivores and one large carnivore) for the period 2007-2014, in Malapati Safari Area, south-eastern Zimbabwe. These were the African elephant (Loxodonta africana), Cape buffalo (Syncerus caffer), greater kudu (Tragelaphus strepsiceros) and leopard (Panthera pardus).

\section{Materials and Methods}

2.1. Study Area. The study was carried out in Malapati Safari Area (MSA) that lies adjacent to the south-eastern side of GNP (Figure 1). MSA has an area of $157 \mathrm{~km}^{2}$ and was designated as a safari area in 1980 [24, 25], which falls under protected area category VI [26]. MSA is a Zimbabwe Parks and Wildlife Management Authority (ZPWMA) property 
TABLE 1: Linear regression model parameter estimates of the mean trophy size trends for selected wildlife species in Malapati Safari Area for period 2007-2014. Significant trends $(p<0.05)$ are indicated in italic.

\begin{tabular}{lccccc}
\hline Species & $\mathrm{N}$ & $\mathrm{R}^{2}$ & $\mathrm{~B} \pm$ S.E & $t$-statistic & $P$ value \\
\hline African elephant & 44 & 0.418 & $1.95 \pm 0.94$ & 2.07 & -5.31 \\
Cape buffalo & 89 & 0.799 & $-3.17 \pm 0.64$ & 0.020 \\
Greater kudu & 31 & 0.004 & $0.20 \pm 1.15$ & 0.28 & 0.003 \\
Leopard & 15 & 0.626 & $0.22 \pm 0.07$ & 3.17 & 0.0178 \\
\hline
\end{tabular}

which was leased to Chiredzi Rural District Council (CRDC), later subcontracted to safari operator to run the hunting business on their behalf [25]. The area is adjacent to GNP, Mabalauta Field Station, and is part of the Greater Limpopo Transfrontier Park (GLTP). The north-western boundary between Malapati Safari Area and Gonarezhou National Park occurs along Mwenezi River.

The area receives a mean annual rainfall of about 466 $\mathrm{mm}[27]$ and has an average monthly minimum temperature range from $9^{\circ} \mathrm{C}$ in June to $24^{\circ} \mathrm{C}$ in January. In summer, temperatures can be as high as $39^{\circ} \mathrm{C}$ [28]. The vegetation is dominated by mopane (Colophospermum mopane) in association with vast stands of Lebombo ironwood (Androstachys johnsonii) and Combretum woodlands [29]. Common wild herbivore species MSA include African elephant, Cape buffalo, giraffe (Giraffa camelopardalis), greater kudu, waterbuck (Kobus ellipsiprymnus), impala (Aepyceros melampus), zebra (Equus quagga), and nyala (Tragelaphus angasii). Large carnivores include lion (Panthera leo), leopard, and hyena (Crocuta crocuta).

2.2. Study Species and Data Collection. We collected secondary data on trophy size, quota allocation, and offtake of four commonly hunted wildlife species, namely, African elephant, Cape buffalo, greater kudu, and leopard for the period between 2007 and 2014 from records at Mabalauta Field Station, located in southern GNP. These species were selected on the basis of their economic significance and attractiveness within the hunting business. The secondary data for the trophy size of the four species were measured and recorded by experienced parks rangers following the Safari Club International (SCI) scoring system [30]. Data on the spatial distribution of animal kill sites based on the Geographic Positioning System (GPS) coordinates was collected for the year 2014 only as this was not routinely collected in the previous years. We considered a kill site as GPS coordinates where an animal carcass was located after being shot during a trophy hunt.

2.3. Data Analysis. We expressed the total number of harvested individuals for each species per given year from the corresponding allocated quota as percentage quota utilization using the formula: $($ Quota utilization $=[$ Total harvested $/$ Total quota] $x$ 100). Explanatory data analysis on trophy sizes and quota utilization to test whether data met normality assumptions was done using Shapiro-Wilk test. Data with explanatory variables, i.e., trophy size and quota utilization, conformed to normality assumptions. Prior to regression analysis, we plotted normal probability plots and studentized residuals to check if data did not violate the normality assumptions.

We performed two main types of analysis: (1) linear regression analysis to determine the trophy size and quota utilization trends and (2) one sample $t$-test on trophy size to ascertain whether there was any difference between observed trophy size and the minimum SCI score for African elephant (i.e., 90 pounds); Cape buffalo (i.e., 101 inches); greater kudu (i.e., 121 inches); and leopard (i.e., 14 inches). We conducted statistical tests using STATISTICA for Windows version 7 [31], at 5\% level of significance. Data on spatial distribution of trophy animal kill sites were used to create a layer processed in Arc GIS 10.2.1 (ESRI Redlands, CA, USA). We used the buffer wizard tool in ArcGIS to create a double buffer measuring (e.g., $0-400 \mathrm{~m}$ and $400-800 \mathrm{~m}$ ) from the GNP boundary extending into MSA. This buffering system was used because the Zimbabwe Parks and Wildlife Management Authority enforces a statutory instrument prohibiting hunting activities within $400 \mathrm{~m}$ from the national park boundary [18]. The proportions of trophy animal kill sites for each species within the buffer areas were later established.

\section{Results}

3.1. Trophy Size Trends. Mean trophy size for African elephant and leopard in Malapati Safari Area showed an increasing trend for the period 2007-2014 (Table 1). In contrast, the trophy size for greater kudu for the period 2007-2014 did not change $\left(R^{2}=0.004, p=0.778\right)$. However, the mean trophy size for Cape buffalo declined significantly $\left(\mathrm{R}^{2}=0.779, \mathrm{p}=0.020\right)$ for the time period 2007-2014 (Figure 2).

Despite the increasing trend in the African elephant trophy size, their mean trophy score $(76.21 \pm 26.79)$ for the period 2007-2014 was significantly lower $\left(\mathrm{t}_{(44)}=-3.41, \mathrm{p}<\right.$ 0.001 ) than the SCI minimum score for the same period. Similarly, Cape buffalo mean trophy size score $(93.77 \pm 15.03)$ was lower than the expected SCI minimum score $\left(\mathrm{t}_{(89)}=4.54\right.$, $\mathrm{p}<0.000$; Table 2), for the same period. On the contrary, the mean trophy sizes for greater kudu $(137.86 \pm 9.33)$ and leopard $(15.07 \pm 0.69)$ were significantly higher than the SCI minimum scores of 121 and 14 inches, respectively, for the period 2007-2014 (Table 2).

3.2. Quota Utilization. Cape buffalo quota utilization increased significantly $\left(\mathrm{R}^{2}=0.62, \mathrm{p}=0.023\right)$ from as low as $67 \%$ to $75 \%$ for the period 2007 to 2014 (Table 3; Figure 3). However, the changes in quota utilization for African elephant, greater kudu, and leopard were not significant. 


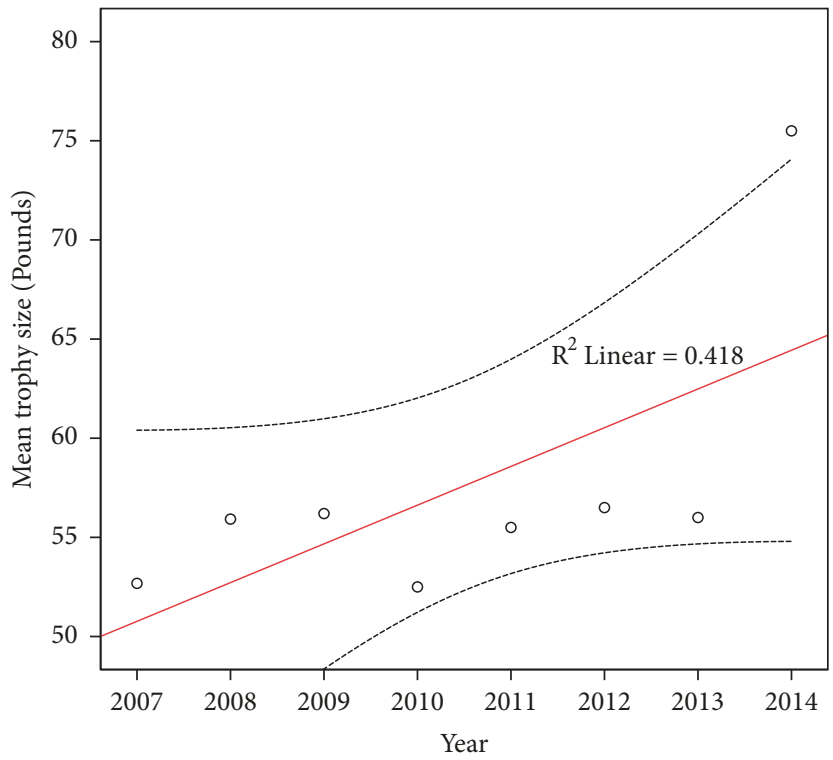

(a) African elephant

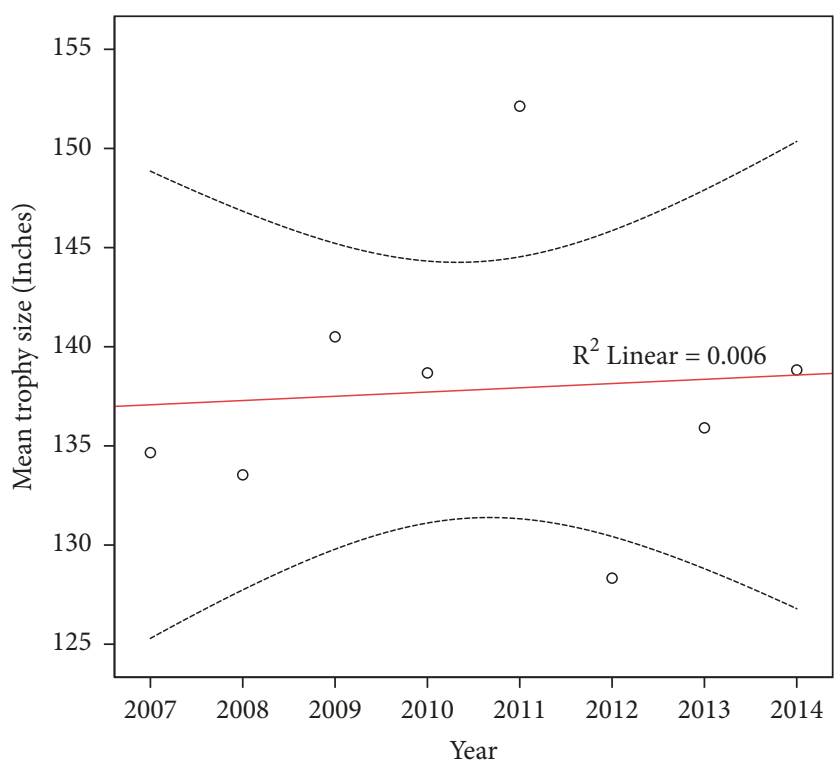

(c) Greater kudu

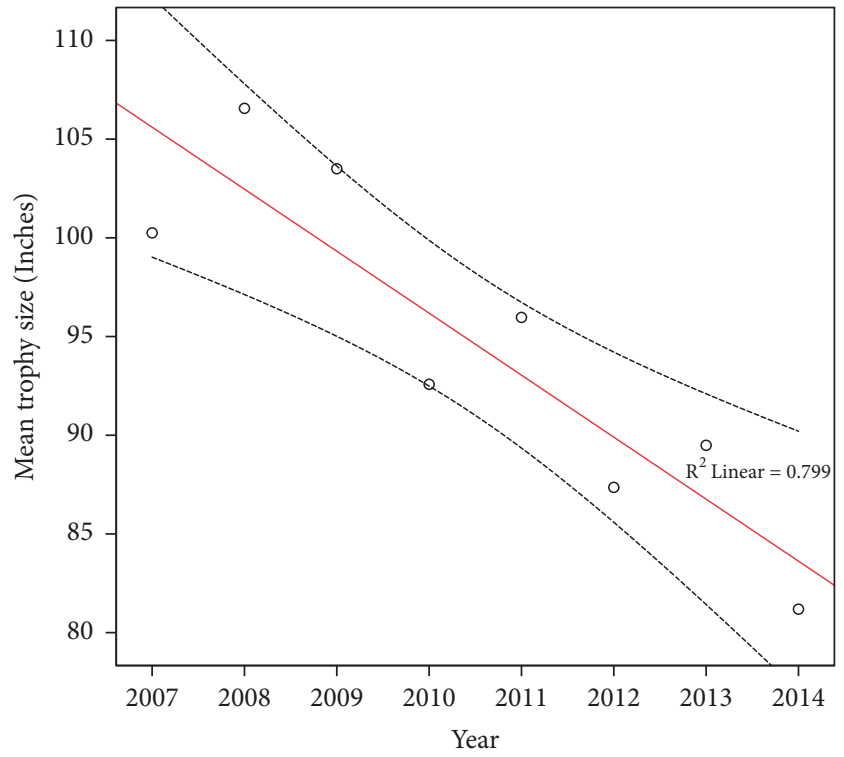

(b) Cape buffalo

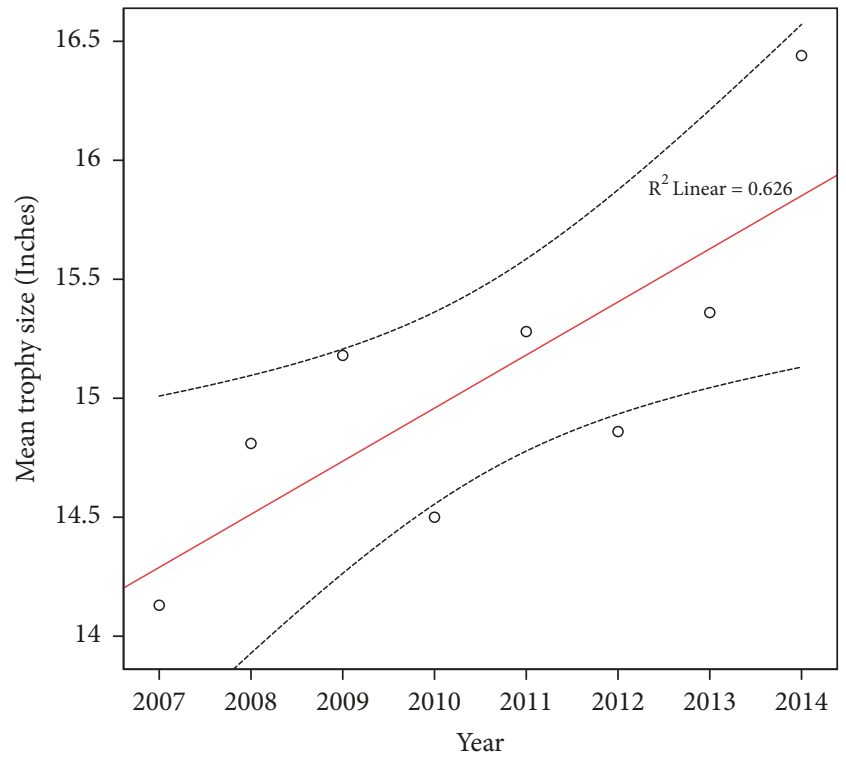

(d) Leopard

FiguRE 2: Temporal trend in mean trophy size (with 95\% confidence interval) for selected wildlife species: (a) African elephant, (b) Cape buffalo, (c) Greater kudu, and (d) Leopard for period 2007-2014 in Malapati Safari Area, southeast of Gonarezhou National Park, Zimbabwe.

TABLE 2: Mean trophy size (mean \pm SD) and the Safari Club International (SCI) minimum scores for selected wildlife species in Malapati Safari Area for the period 2007-2014. Notes: N: total number of individuals harvested for the period 2007-2014.

\begin{tabular}{llccccc}
\hline Species & $\mathrm{N}$ & Mean \pm SD & SCI minimum Score (Inches) & df & $t$-statistic & $P$ value \\
\hline African elephant & 44 & $76.21 \pm 26.79$ & 90 & 43 & -3.41 & 0.001 \\
Cape buffalo & 89 & $93.77 \pm 15.03$ & 101 & 88 & -4.54 \\
Greater kudu & 31 & $137.86 \pm 9.33$ & 121 & 30 & 10.06 \\
Leopard & 15 & $15.12 \pm 1.68$ & 14 & 14 & 2.59 & 0.001 \\
\hline
\end{tabular}


TABLE 3: Linear regression parameter estimates for quota utilization of selected wildlife species for the period 2007-2014 in Malapati Safari Area, southeast of Gonarezhou National Park, Zimbabwe.

\begin{tabular}{|c|c|c|c|c|c|}
\hline Species & $\begin{array}{c}\text { Mean } \pm \text { SD Quota } \\
\text { utilization }(\%)\end{array}$ & $\mathrm{R} 2$ & $\beta \pm \mathrm{SE}$ & t-statistic & $P$ value \\
\hline African elephant & $97.88 \pm 6.01$ & 0.76 & $-0.61 \pm 0.97$ & -0.63 & 0.560 \\
\hline Cape buffalo & $75.00 \pm 9.80$ & 0.61 & $3.14 \pm 1.01$ & 3.11 & 0.023 \\
\hline Greater kudu & $77.50 \pm 16.69$ & 0.06 & $1.67 \pm 2.70$ & 0.62 & 0.559 \\
\hline Leopard & $58.38 \pm 23.79$ & 0.06 & $-2.42 \pm 3.84$ & -0.63 & 0.555 \\
\hline
\end{tabular}

TABLE 4: Proportion of 2014 kill sites occurrence and their distribution in and around Malapati Safari Area, southeast of Gonarezhou National Park, Zimbabwe.

\begin{tabular}{lccccc}
\hline \multirow{2}{*}{ Species } & 2014 & \multicolumn{2}{c}{ Proportion of occurrence (\%) } \\
& Offtake (N) & Inside MSA & Within buffer area & Inside GNP & Communal Areas \\
\hline African elephant & 6 & 33.33 & 16.67 & $*$ & 50.00 \\
Cape buffalo & 14 & 64.29 & 14.29 & $* 14$ & 14.29 \\
Greater kudu & 5 & 100.00 & $*$ & $*$ & $*$ \\
Leopard & 1 & $*$ & $*$ & $* 00$ \\
\hline
\end{tabular}

3.3. Spatial Distribution of Kill Sites. For the 2014 hunting season, our results showed that most African elephant, Cape buffalo, and greater kudu kill sites were located closer to the GNP boundary or along rivers occurring in MSA (Figure 4). About $16.67 \%$ and $14.29 \%$ of African elephant and Cape buffalo kill sites occurred within the restricted $400 \mathrm{~m}$ buffer area from the park boundary. Greater kudu kill sites all occurred inside MSA. However, the only leopard kill site for the year 2014 occurred outside MSA (Table 4).

\section{Discussion}

Our results showed a declining trend in trophy size in Cape buffalo trophies over time in Malapati Safari Area. Similar declines in Cape buffalo trends were also reported in Sengwa Wildlife Research Area, northwest Zimbabwe [32], as well as in Selous Game Reserve, Tanzania, and South Africa [12]. The declines in Cape buffalo trophy size could be attributed to the harvesting regimes and trophy hunting pressure [8]. In MSA, trophy hunting pressure has been reported to have reduced densities of common large herbivores [33] and illegal bushmeat trade where Cape buffalo is one of the key target species in in this area $[34,35]$.

The SCI scoring system has some limitations particularly in Cape buffalo trophies where high SCI scoring trophies may be from soft bossed males (green bull) in prime reproduction stage. In some cases, older bulls with broomed horns, an indication of old age for individuals that are past reproduction, tend to have low SCI scores $[8,36]$. We argue that low trophy scores mostly from Cape buffalo males with broomed horns are not an indication of poor trophy quality but rather depict sustainable harvesting practices [37].

In this study, we observed significant increases in trophy size for Africa elephant in MSA between 2007 and 2014. The increasing trend in elephant trophy size in MSA confirms the notion that the broader Gonarezhou area is renowned for its large tusker African elephants [38]. This presupposes the existence of source and sink dynamics in trophy individuals, where Malapati Safari Area acts as a sink with the GNP being the source of big tuskers over time [39]. However, our findings were contrary to those found in Matetsi Safari Area, Zimbabwe [8], in Sengwa Wildlife Research Area, Zimbabwe [32], and Selous Game Reserve, Tanzania [40], where declining African elephant trophy sizes were reported. Nonetheless, African elephant trophy sizes were below the minimum SCI score of 90 pounds. Trophy sizes below minimum SCI score suggest the harvesting of young bulls which has negative impacts on population structure and future breeding patterns [41]. Over time, there is loss of trophy hunting induced behavioural adaptation by older African elephant bulls such as avoidance of risky hunting areas [11, 42] which tends to affect social cohesion and survival of breeding herds.

Leopard trophy sizes were above the minimum SCI minimum score of 14 inches and increased over the period 2007-2014. The increasing trophy size trend in leopard is supposedly a result of low hunting pressure and fairly healthy population densities of the species in the study area. We argue that sustainable harvesting practices such as low offtake levels in large carnivores promote the survival and persistence of harvested populations [43]. However, increased hunting pressure compromises trophy sizes of hunted carnivore species as observed for leopard in Kwazulu Natal, South Africa, due to [44], and in Selous Game Reserve, Tanzania [40].

The significant increase in the African elephant and Cape buffalo quota utilization (2007-2014) could be a result of the attractiveness and the demand for African elephant and Cape buffalo trophies [13, 37]. African elephant and Cape buffalo are the major attraction for hunting clients coming to hunt in MSA. These two species are considered as the major economic returns for hunting safari business in MSA and other similar areas in Zimbabwe. Leopard quotas may have been maintained constant and relatively low as a sustainable harvesting strategy in MSA thus resulting in desirable trophies and fairly high quota utilization rates. Management 


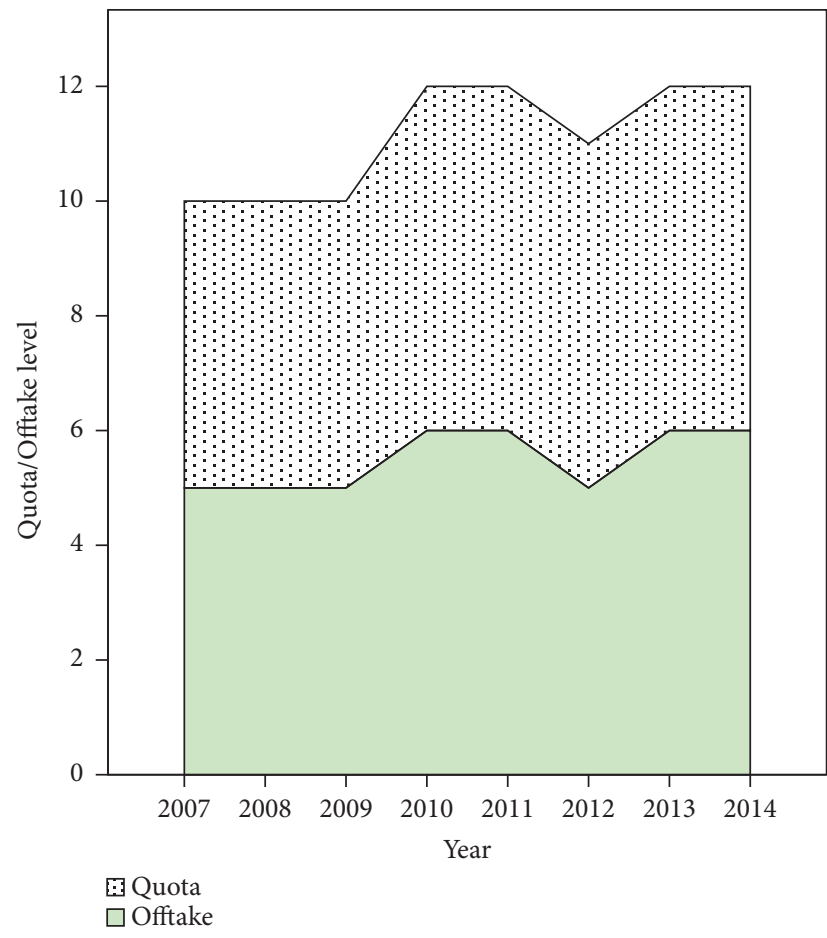

(a) African elephant

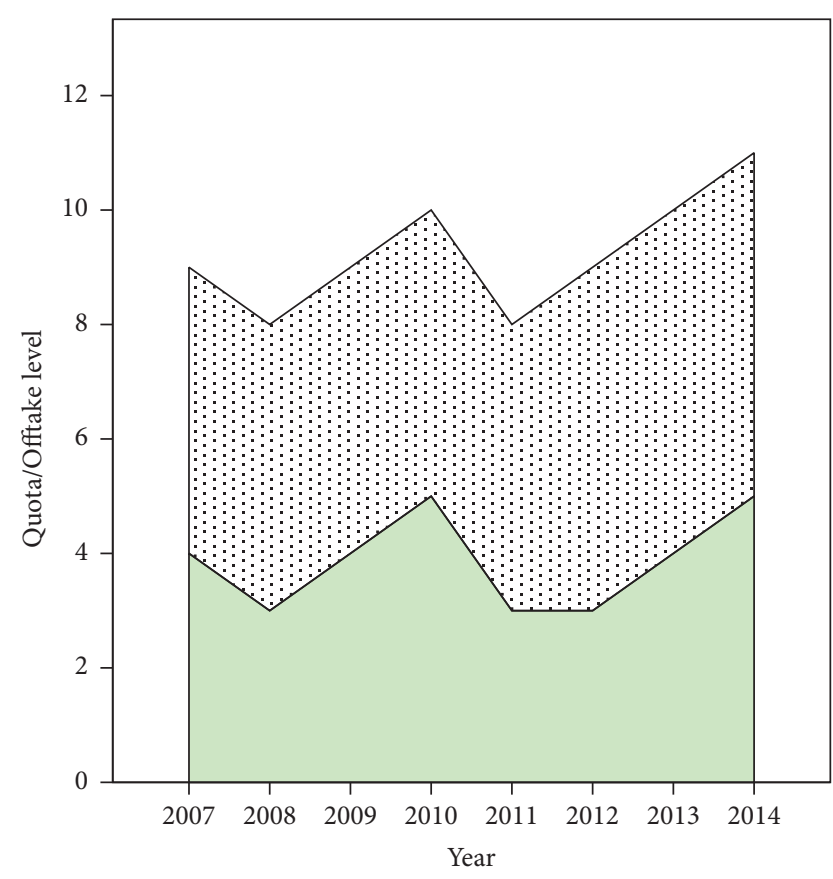

[.] Quota $\square$ Offtake

(c) Greater kudu

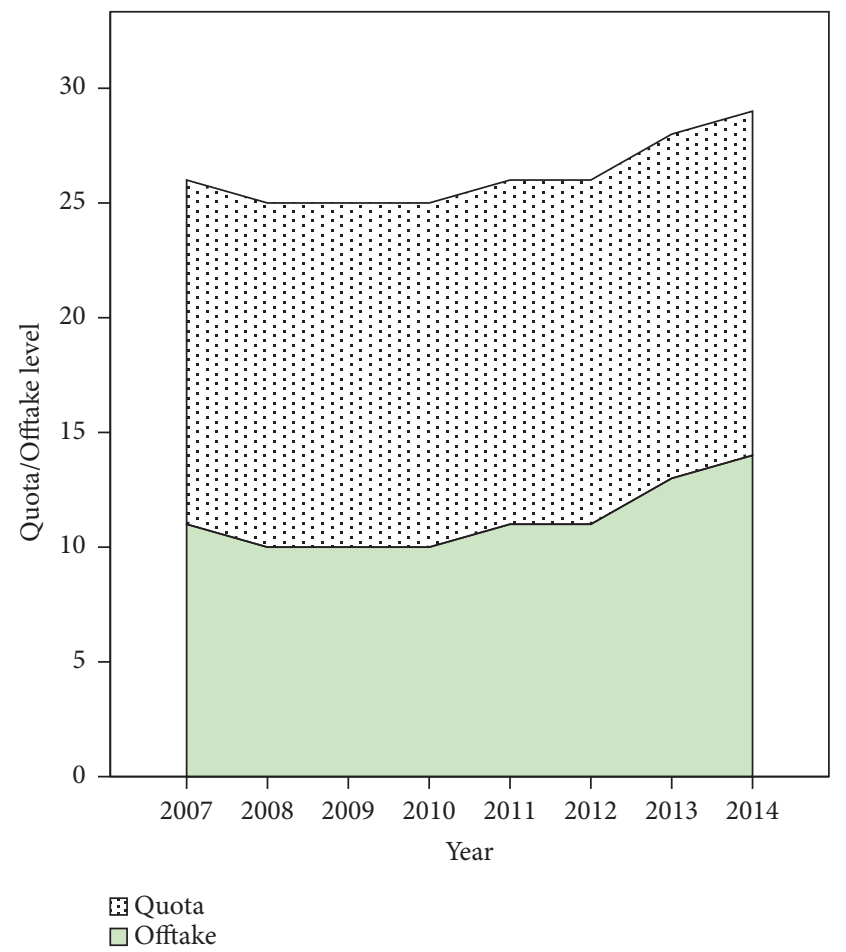

(b) Cape buffalo

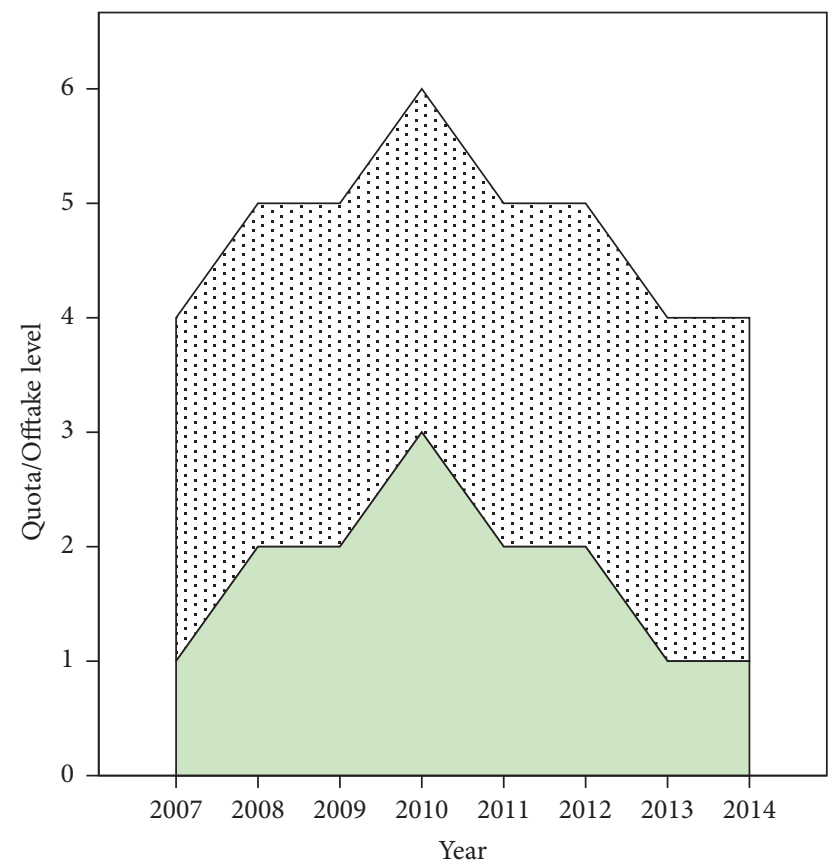

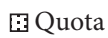

$\square$ Offtake

(d) Leopard

FIGURE 3: Quota allocation and offtake levels for selected wildlife species: (a) African elephant (b) Cape buffalo, (c) Greater kudu, and (d) leopard for the period 2007-2014 in Malapati Safari Area, southeast of Gonarezhou National Park, Zimbabwe. 


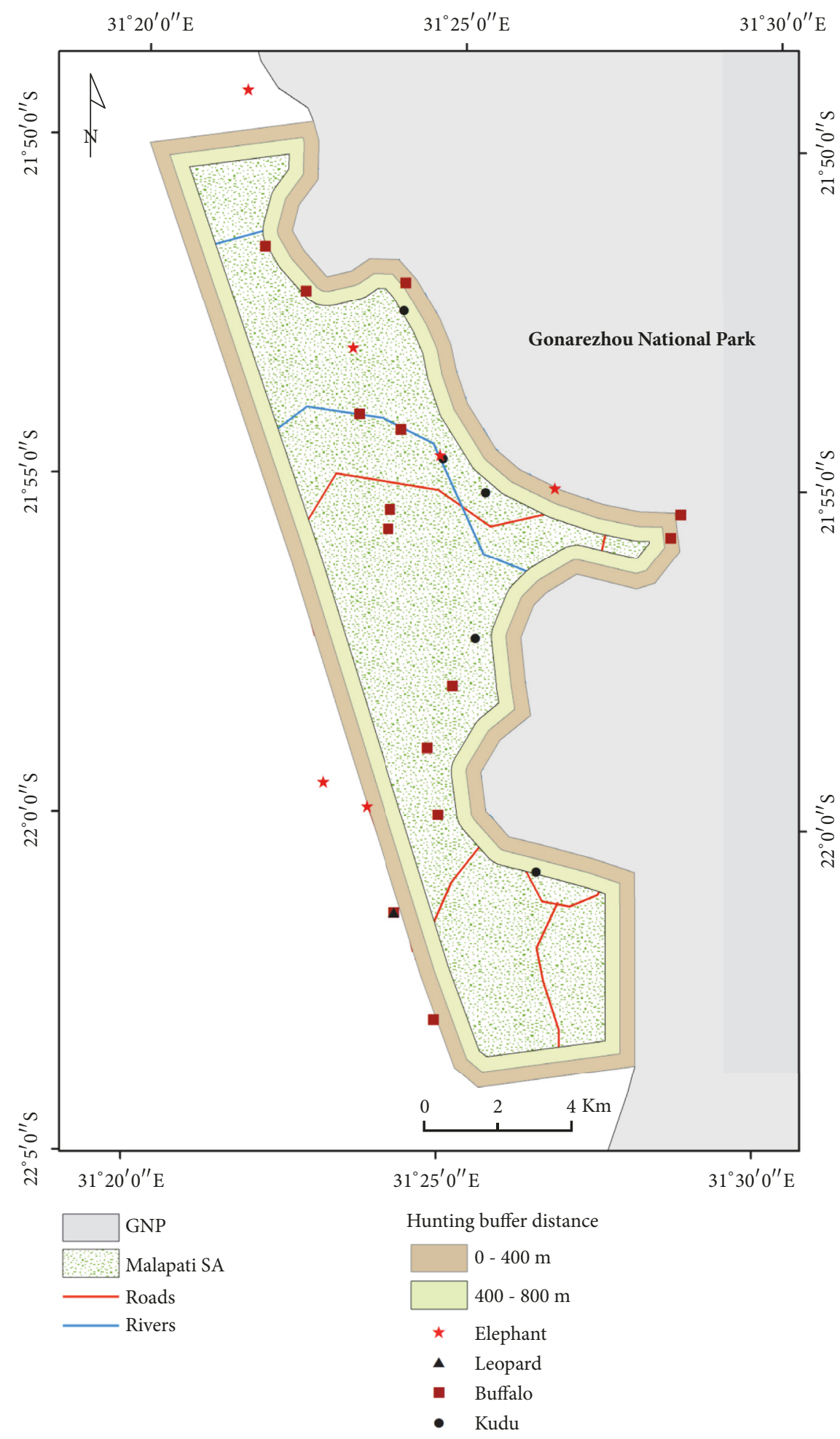

FIGURE 4: Spatial distribution of 2014 trophy kill-sites for the selected four wildlife species in relation to southern Gonarezhou national Park boundary, southeast of Gonarezhou National Park, Zimbabwe.

should promote sustainable harvesting strategies for these preferred species to minimise possible phenotypic plasticity through loss of the desirable traits, e.g., big horns or tusks [11].
The occurrence of African elephant and Cape buffalo kill sites within the restricted $400 \mathrm{~m}$ buffer zone could be associated with their foraging behaviour especially near water sources [45, 46]. Apparently, the boundary between Malapati 
Safari Area and Gonarezhou National Park occurs along Mwenezi River. The wide distribution of African elephant kill sites in the safari area could be attributed to their free roaming behaviour [41]. The position of a kill site is also influenced by shot placement which in turn is affected by vegetation cover among other factors [47]. Nonetheless, the presence of animal kill sites in restricted zones violates provisions of the Statutory Instrument 362 of 1990 of the Parks and Wildlife Act of Zimbabwe on restrictions and prohibitions on hunting areas. There is need to promote responsible and ethical hunting practices to ensure that trophy hunting is sustainable and continues to contribute towards conservation. The possible existence of source and sink dynamics between GNP and MSA, respectively, within the Greater Limpopo Transfrontier Park (GLTP) requires a more careful approach to ensure that robust scientific and monitoring programs are promoted to enhance the sustainability of trophy hunting as a conservation tool.

\section{Conclusion}

We conclude that MSA has experienced variable trophy hunting impacts as indicated by the trophies below minimum SCI scores, e.g., African elephant and Cape buffalo. Trophy size trends for greater kudu and leopard indicate that, where sustainable quotas are implemented, trophy hunting does not compromise the trophy quality of harvested species. Occurrence of some kill sites within prohibited buffer zone and park suggests the possible existence of source and sink dynamics between nonhunting and the hunting area. We recommend the following: (1) the need for more scientifically robust, adaptable, and participatory quota setting process, (2) enhanced adherence to good practice in terms of ethical hunting conduct, and (3) development of a robust hunting monitoring system on trophy hunting for adaptive wildlife management.

\section{Data Availability}

The data used to support the findings of this study are available from the corresponding author upon request.

\section{Disclosure}

Present address of "Daphine Madhlamoto" is Mushandike College of Wildlife Management, Parks and Wildlife Management Authority, Private Bag 9036, Masvingo, Zimbabwe.

\section{Conflicts of Interest}

The authors have no conflicts of interest to declare.

\section{Acknowledgments}

The authors acknowledge the Director-General of the Zimbabwe Parks and Wildlife Management Authority for allowing them to conduct this research and for the permission to publish this work. They are also grateful to the management staff and rangers of Mabalauta Field Station for their support during the course of the study. Many thanks are due to Mr. N. Dzingai, Simon Dzingai, Mr. N. Makanasi, and the Chiredzi Rural District Council and CAMPFIRE staff for their support.

\section{References}

[1] P. A. Lindsey, "Trophy hunting in sub-Saharan Africa: economic scale and conservation significance," in Best Practices in Sustainable Hunting-A Guide to Best Practices from Around the World, R. D. Baldus, G. R. Damm, and K. Wollscheid, Eds., pp. 41-47, Hungary International Council for Game and Wildlife Conservation, 2008.

[2] J. E. Mbaiwa, "Effects of the safari hunting tourism ban on rural livelihoods and wildlife conservation in Northern Botswana," South African Geographical Journal, vol. 100, no. 1, pp. 41-61, 2018.

[3] P. A. Lindsey, L. G. Frank, R. Alexander, A. Mathieson, and S. S. Romañach, "Trophy hunting and conservation in africa: problems and one potential solution," Conservation Biology, vol. 21, no. 3, pp. 880-883, 2007.

[4] E. J. Milner-Gulland, N. Bunnefeld, and G. Proaktor, "The science of sustainable hunting," in Recreational Hunting, Conservation and Rural Livelihoods, B. Dickson, J. Hutton, and B. Adams, Eds., pp. 75-93, John Wiley \& Sons, Oxford, UK, 2009.

[5] W. J. Sutherland, "Sustainable exploitation: a review of principles and methods," Wildlife Biology, vol. 7, no. 3, pp. 131-140, 2001.

[6] G. R. Damm, "Recreational trophy hunting: "what do we know and what should we do?"," in Best Practices in Sustainable Hunting-A Guide to Bes Practices from around the World, R. D. Baldus, G. R. Damm, and K. Wollscheid, Eds., pp. 5-11, International Council for Game and Wildlife Conservation, Hungary, 2008.

[7] R. Buckley and A. Mossaz, "Hunting tourism and animal conservation," Animal Conservation, vol. 18, no. 2, pp. 133-135, 2015.

[8] V. K. Muposhi, E. Gandiwa, P. Bartels, S. M. Makuza, and T. H. Madiri, "Trophy hunting and sustainability: Temporal dynamics in trophy quality and harvesting patterns of wild herbivores in a tropical semi-arid savanna ecosystem," PLoS ONE, vol. 11, Article ID e0164429, 2016.

[9] D. W. Coltman, P. O’Donoghue, J. T. Jorgenson, J. T. Hogg, C. Strobeck, and M. Festa-Bianchet, "Undesirable evolutionary consequences of trophy hunting," Nature, vol. 426, no. 6967, pp. 655-658, 2003.

[10] F. W. Allendorf and J. J. Hard, "Human-induced evolution caused by unnatural selection through harvest of wild animals," Proceedings of the National Academy of Sciences, vol. 106, pp. 9987-9994, 2009.

[11] V. K. Muposhi, E. Gandiwa, S. M. Makuza, and P. Bartels, "Ecological, physiological, genetic trade-offs and socio-economic implications of trophy hunting as a conservation tool: A narrative review," Journal of Animal and Plant Sciences, vol. 27, no. 1, pp. 1-14, 2017.

[12] R. G. von Brandis and B. K. Reilly, "Spatial variation in trophy quality of popular hunted ungulate species in South Africa," South African Journal of Wildlife Research, vol. 38, no. 1, pp. 1721, 2008. 
[13] R. G. von Brandis and B. K. Reilly, "A temporal analysis of trophy quality in South Africa: has trophy quality changed over time," South African Journal of Wildlife Research, vol. 37, no. 2, pp. 153158, 2007.

[14] W.-G. Crosmary, A. J. Loveridge, H. Ndaimani et al., "Trophy hunting in Africa: long-term trends in antelope horn size," Animal Conservation, vol. 16, no. 6, pp. 648-660, 2013.

[15] J. M. Pérez, E. Serrano, M. González-Candela et al., "Reduced horn size in two wild trophy-hunted species of Caprinae," Wildlife Biology, vol. 17, no. 1, pp. 102-112, 2011.

[16] L. Radder and T. Bech-Larsen, "Hunters' motivations and values: A South African perspective," Human Dimensions of Wildlife, vol. 13, no. 4, pp. 252-262, 2008.

[17] A. Woods and G. N. Kerr, "Recreational game hunting: motivations, satisfactions and participation," Land Environment and People Research Report No 18, Lincoln University, Canterbury, New Zealand, 2010.

[18] V. K. Muposhi, E. Gandiwa, P. Bartels, and S. M. Makuza, "Trophy hunting, conservation, and rural development in Zimbabwe: issues, options, and implications," International Journal of Biodiversity, vol. 2016, Article ID 8763980, 16 pages, 2016.

[19] A. R. Watkinson and W. J. Sutherland, "Sources, sinks and pseudo-sinks," Journal of Animal Ecology, vol. 64, no. 1, pp. 126130, 1995.

[20] P. C. Dias, "Sources and sinks in population biology," Trends in Ecology \& Evolution, vol. 11, no. 8, pp. 326-330, 1996.

[21] M. Festa-Bianchet, "When does selective hunting select, how can we tell, and what should we do about it?" Mammal Review, vol. 47, no. 1, pp. 76-81, 2017.

[22] B. Tenhumberg, A. J. Tyre, A. R. Pople, and H. P. Possingham, "Do harvest refuges buffer kangaroos against evolutionary responses to selective harvesting?” Ecology, vol. 85, no. 7, pp. 2003-2017, 2004.

[23] F. Pelletier, M. Festa-Bianchet, J. T. Jorgenson, C. Feder, and A. Hubbs, "Can phenotypic rescue from harvest refuges buffer wild sheep from selective hunting?” Ecology and Evolution, vol. 4, no. 17, pp. 3375-3382, 2014.

[24] J. J. Blanc, African elephant status report 2007: an update from the African elephant database: IUCN, 2007.

[25] J. Andersson, M. de Garine-Wichatitsky, D. Cumming, V. Dzingirai, and K. Giller, Transfrontier Conservation Areas: People Living on the Edge, Taylor \& Francis, 2017.

[26] H. Locke and P. Dearden, "Rethinking protected area categories and the new paradigm," Environmental Conservation, vol. 32, no. 1, pp. 1-10, 2005.

[27] X. Poshiwa, R. A. Groeneveld, I. M. A. Heitkönig, H. Prins, and E. Van Ierland, "Reducing rural households' annual income fluctuations due to rainfall variation through diversification of wildlife use: portfolio theory in a case study of south eastern Zimbabwe," Tropical Conservation Science, vol. 6, no. 2, pp. 201220, 2013

[28] E. Gandiwa and S. Kativu, "Influence of fire frequency on colophospermum mopane and combretum apeculatum woodland structure and composition in northern GNP. Zimbabwe," Journal of Tropicl Ecology, vol. 51, 2009.

[29] T. W. Gara, A. Murwira, E. Chivhenge, T. Dube, and T. Bangira, "Estimating wood volume from canopy area in deciduous woodlands of Zimbabwe," Southern Forests: A Journal of Forest Science, vol. 76, no. 4, pp. 237-244, 2014.

[30] SCI, Safari Club International, Trophy Records World Hunting Awards, Tucson, Ariz, USA, 2008.
[31] StatSoft, STATISTICA for Windows Version 7.0, StatSoft, Oklahoma, Okla, USA, 2006.

[32] P. Ngorima, "Analysis of trends on trophy quality of African elephant, lion, buffalo and stakeholders perceptions in Sengwa Wildlife Research Area, Zimbabwe from 2003 to 2013," 2016.

[33] T. Ndiweni, P. Zisadza-Gandiwa, H. Ncube, C. Mashapa, and E. Gandiwa, "Vigilance behavior and population density of common large herbivores in a southern african savanna," Journal of Animal and Plant Sciences, vol. 25, no. 3, pp. 876-883, 2015.

[34] E. Gandiwa, "Preliminary assessment of illegal hunting by communities adjacent to the northern Gonarezhou National Park, Zimbabwe," Tropical Conservation Science, vol. 4, no. 4, pp. 445-467, 2011.

[35] P. A. Lindsey, S. S. Romañach, S. Matema, C. Matema, I. Mupamhadzi, and J. Muvengwi, "Dynamics and underlying causes of illegal bushmeat trade in Zimbabwe," Oryx, vol. 45, no. 1, pp. 84-95, 2011.

[36] S. E. Gandy and B. K. Reilly, "Altertative trophy measuring techniques for African buffalo," Koedoe, vol. 47, no. 1, pp. 119124, 2004.

[37] W. Taylor, "The influence of trophy measurement in cape buffalo," African Indaba, vol. 5, 2007.

[38] ZPWMA, Gonarezhou National Park Management Plan (20112011), Zimbabwe Parks and Wildlife Management Authority, Harare, Zimbabwe, 2010.

[39] J. I. Schmidt, J. M. Ver Hoef, and R. T. Bowyer, "Antler size of Alaskan moose Alces alces gigas: Effects of population density, hunter harvest and use of guides," Wildlife Biology, vol. 13, no. 1, pp. 53-65, 2007.

[40] A. N. Songorwa and M. du Toil, "Hunting in Tanzania: has science played its role?" Tanzania Journal of Agricutural Science, vol. 8, pp. 31-38, 2008.

[41] S.-A. J. Selier, B. R. Page, A. T. Vanak, and R. Slotow, "Sustainability of elephant hunting across international borders in southern africa: a case study of the greater mapungubwe transfrontier conservation area," The Journal of Wildlife Management, vol. 78, no. 1, pp. 122-132, 2014.

[42] V. K. Muposhi, E. Gandiwa, S. M. Makuza, and P. Bartels, "Trophy hunting and perceived risk in closed ecosystems: flight behaviour of three gregarious african ungulates in a semi-arid tropical savanna," Austral Ecology, vol. 41, no. 7, pp. 809-818, 2016.

[43] A. J. Loveridge, J. C. Reynolds, and E. Milner-Gulland, "Does sport hunting benefit conservation," Key Topics in Conservation Biology, vol. 1, p. 222, 2007.

[44] G. A. Balme, R. Slotow, and L. T. B. Hunter, "Edge effects and the impact of non-protected areas in carnivore conservation: leopards in the Phinda-Mkhuze Complex, South Africa," Animal Conservation, vol. 13, no. 3, pp. 315-323, 2010.

[45] V. K. Muposhi, A. Chanyandura, E. Gandiwa et al., "Postrelease monitoring of diet profile and diet quality of reintroduced African buffalo (Syncerus caffer) in Umfurudzi Park, Zimbabwe," Tropical Conservation Science, vol. 7, no. 3, pp. 440456, 2014.

[46] V. K. Muposhi, E. Gandiwa, A. Chemura, P. Bartels, S. M. Makuza, and T. H. Madiri, "Habitat heterogeneity variably influences habitat selection by wild berbivores in a semi-arid tropical savanna ecosystem," PLoS ONE, vol. 11, no. 9, Article ID 0163084, 2016.

[47] L. Grange, Ballistics in Perspective: A Guide in Weapon Choice in the Hunting of Game in Zimbabwe, Harare, Zimbabwe, 1983. 


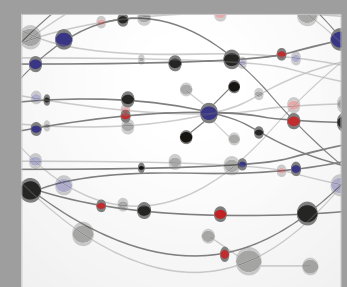

The Scientific World Journal
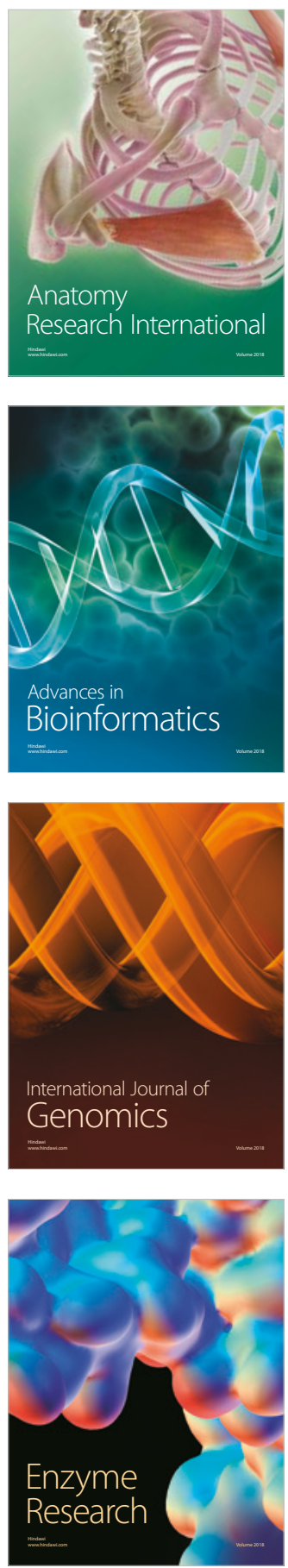
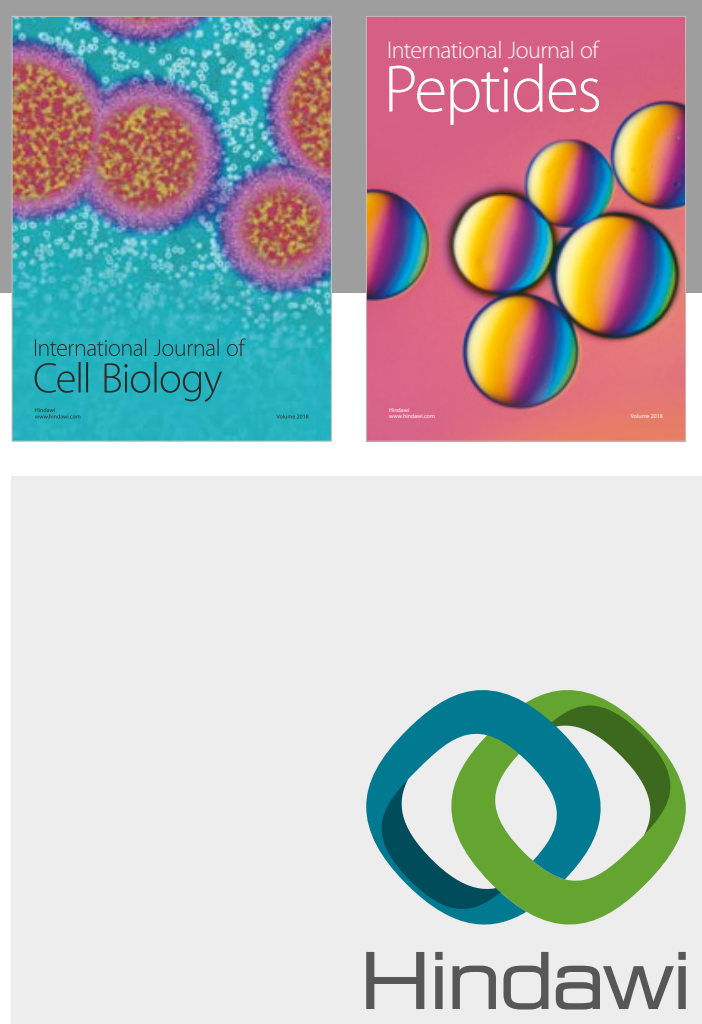

Submit your manuscripts at

www.hindawi.com
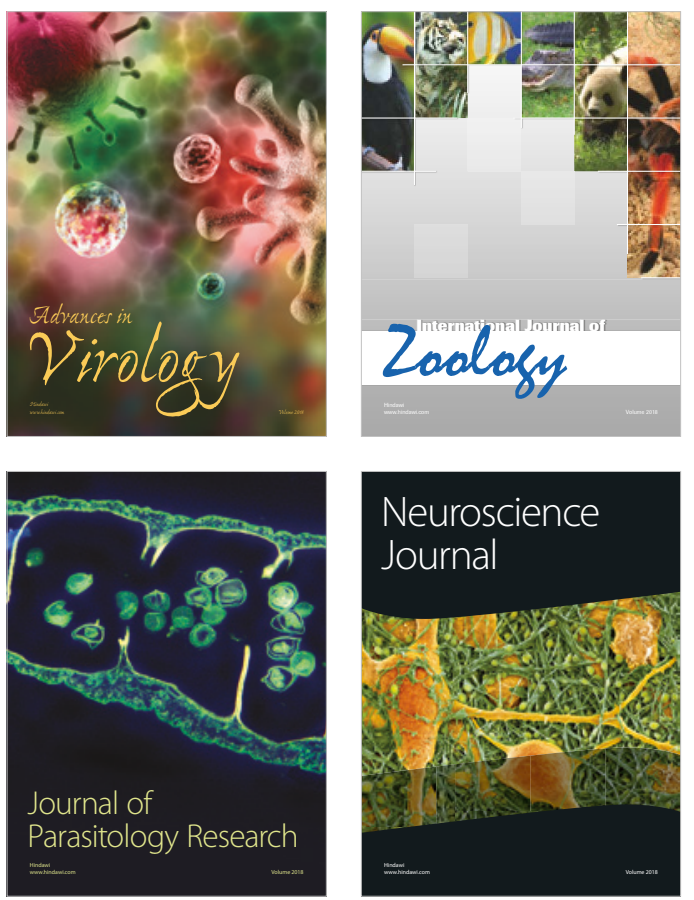
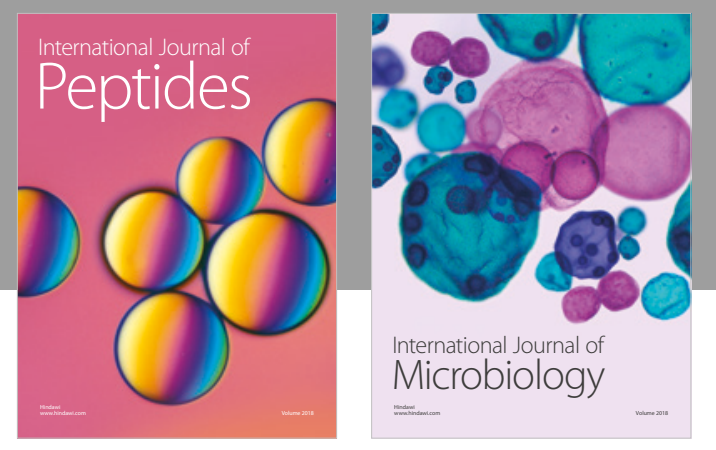

nternational Journal of Microbiology
Journal of
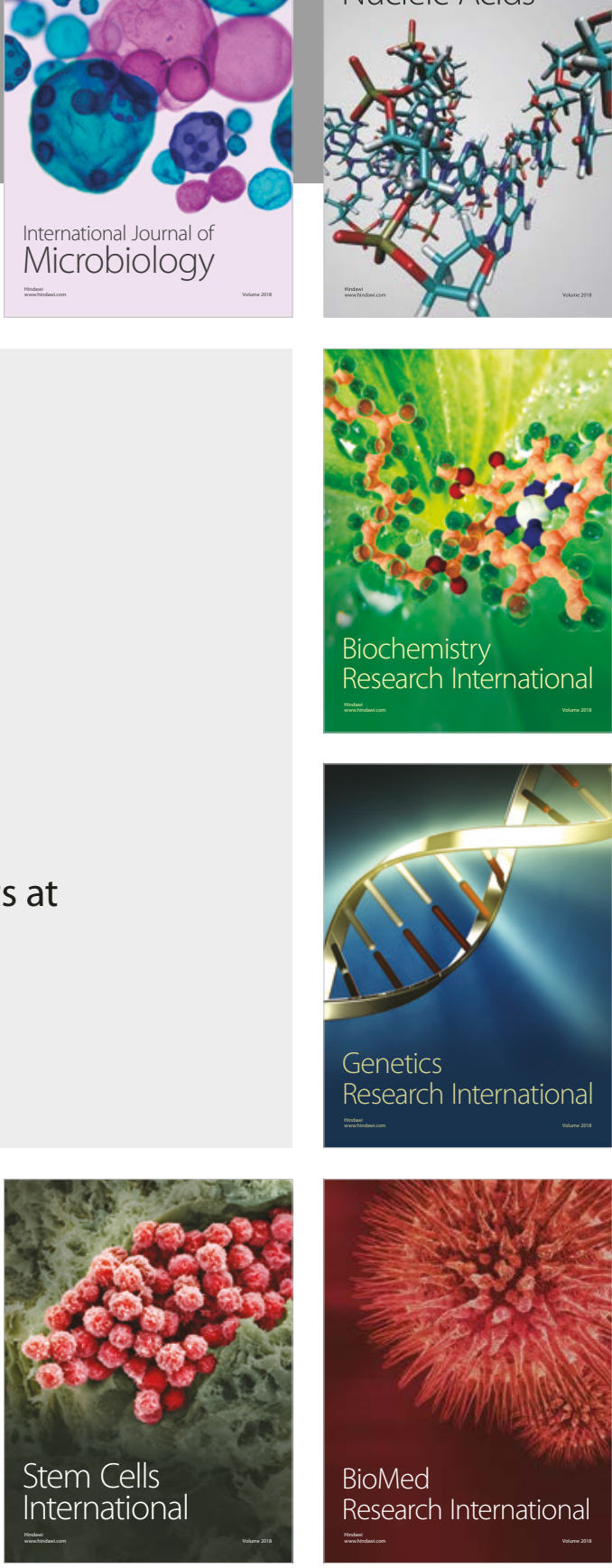
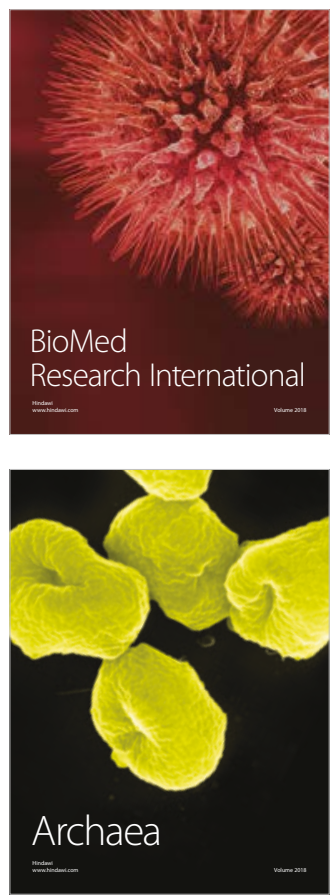